\title{
Excavating Collections: Archaeological Finds at the Redpath Museum
}

\author{
by Michael Bisson, Barbara Lawson, and Bruce Trigger
}

Two research projects relating to the Redpath Museum's archaeology collections are described as part of a general discussion of the value and future role of such collections. One project involved the discovery at the Museum of an important piece of Meroitic art dating from the first century A.D. and of the cast of a companion piece, both of which had been lost track of after they wre displayed in Liverpool in 1914. The second project concerned the use of stone tools and bones in the Redpath Museum to help date and confirm the original place of discovery of a number of European Palaeolithic figurines purchased in a Montreal antique shop in 1990. These discoveries illustrate the research potential of these long neglected and little known collections. It is argued that, as ever more archaeological sites are destroyed as a result of population growth and economic development, museum collections will become an increasingly important source of information about the past.

Deux projets de recherche sur les collections archéologiques du Musée Redpath sont décrits dans le cadre d'un débat plus vaste sur la valeur et le futur rôle de ces collections. L'un des projets porte sur la découverte au Musée d'un important artefact méroitique datant du $1^{\sigma r}$ siècle après $J$. -C. et du moule d'une pièce semblable qui avaient disparu après qu'ils eurent été exposés à Liverpool en 1914. Le deuxième projet porte sur l'utilisation d'os et d'outils en pierre du Musée Redpath pour dater et confirmer l'origine de plusieurs figurines européennes du Paléolithique achetées chez un antiquaire montréalais en 1990. Ces découvertes illustrent le potentiel de recherche de ces collections à la fois négligées et méconnues. Les auteurs prétendent que dans la mesure où de plus en plus de sites archéologiques sont détruits par la croissance démographique et les collections du musée deviendront une source de plus en plus précieuse de renseignements sur le passé.

A rchaeologists face a dilemma. Material excavated in the past was recovered at a time when archaeological theory and methods were less developed and when excavation and recording standards generally were inferior to what they are today. The precise context in which artifacts were discovered frequently went unrecorded and material that was not thought to be of interest was discarded. As a result, much information that today would be considered invaluable for radiocarbon dating, identifying plants, animals, and palaeoclimatic conditions, and studying ancient technologies and social life was lost forever. Even the artifacts that were saved often were allotted to a number of different museums and material from the same site became disaggregated in museum cataloguing and storage systems. For all these reasons archaeologists generally do not regard old archaeological collections as being a significant source of information about the past.'

Today, however, archaeologists are witnessing the massive destruction of the archaeological record in most parts of the world as the result of rapid population growth and the increasingly intensive exploitation of the environment. Despite extensive and often well-funded efforts to locate, preserve, and if necessary excavate archaeological sites that are being threatened by development, in most regions archaeological sites are being destroyed more quickly than archaeologists can study them. ${ }^{2}$ Given the rapid escalation of technological development, it is possible to envisage a future when archaeological techniques will have advanced far beyond their present standards, but when few, if any, archaeological sites will survive to be excavated. Under these circumstances, the most exciting and important archaeological discoveries may be made in museums rather than in excavations.

In recent years, holdings in the Redpath Museum have shed light on archaeological matters of international importance. Compared to those in many other museums, the archaeological holdings at the Redpath Museum are small and do not embrace numerous objects of major aesthetic or historical 
Perter Radpath Museuy op MCGill IJNiversity.

$$
\text { GUIDE TO VISITOIRS. }
$$

[This consiate of the anto-chan ber as the heal of tho frat figlit of stnlrs which is dovoted to Archroological and Palaontulugical spucimens, and the

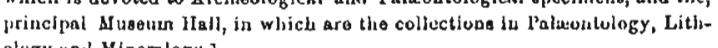
ology und Miaeralogy.

I. ARCRAOLOQICAL AND MYSELLANEOUS COLJFCTIONS IN THE AN"'L-CHAMUE'I A'P HEAD OF THE STAIH.

Cases on left-band side and opposite stairway. Theso contula tho following collections:-

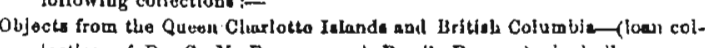

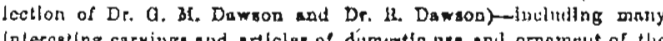

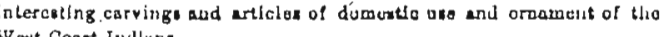

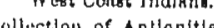

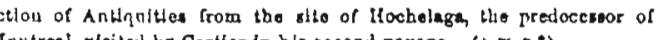

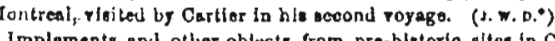

and other objock from pre-biatorio sittes in Cannda and

Objects collocted by liov. II ugh Robertsun in tha New Hlebrides Inlands.

Collections from Pre-bivcorio cavtes in the Lobunon and stone lapplemente fram Egypt (d. \%. D.) The oldort of theso collectlon! belong to P'nllowo. conmio men, contomporary with tho woolly kbinocerion and oller axthice andmsis, phose bones and toeth aro found amoug the debris of tho reparta of this prinaltive peoplo.

Colloctione to illuatrate the varioun rocke snd useful ormemontal stonea

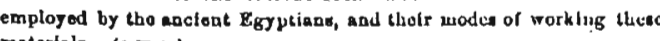
macerins. (J.,. D.)

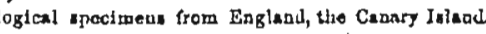
and oleombere

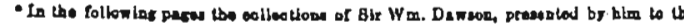

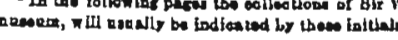

4 GUIDE TO FISITORS

Wall on rigkt-band side. Casts of footprints of Sauroptes unguiver, s largo intrachinn from the coal-formation of Nork Bcotia, and of greac

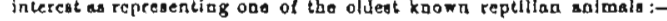

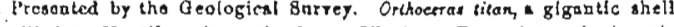
sllled to Nautitua from tho lower Bilurinn. Footprints of gigantlo biped repthes (Brontozoura Je) from tha Trias of Masmacharethe

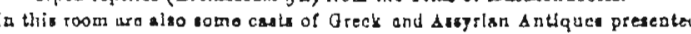

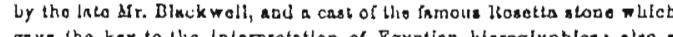
gava tho kay wotho in terpretatos of Egyptlan hioroglyphica; also

Figure 1. Guide to Visitors to the Peter Redpath Museum (1885), pages 3 and 4, lists the archaeological and ethnographic materials on display in the museum. 


\section{Excavating Collections}

importance, such as are regularly displayed in large public museums, even if its mummies and mummy cases have long been among the Museum's major attractions for Montrealers. The Redpath archaeological collections are, however, a valuable teaching aid and have been used as such by the Anthropology, Classics, and Art History departments and by the Faculty of Religious Studies ever since the Ethnology department was established in the Redpath Museum in the early 1970 s.

The two discoveries discussed in this paper illustrate different strengths of the Redpath Museum's archaeological collections. The first is the identification of a long-lost major work of ancient African art. The second is the use of the Redpath's collections of Palaeolithic artifacts to confirm the source and dating of several extraordinarily important pieces of European Upper Palaeolithic art purchased in a Montreal antique store in 1990. The announcement of the results of this study received extensive coverage in the international press. Before describing these two discoveries, we will review briefly the complex history of the archaeological collections currently preserved in the Redpath Museum.

\section{HISTORY OF THE REDPATH'S ARCHAEOLOGY COLLECTIONS}

The Redpath's archaeology collections, which embrace material from many Palaeolithic sites as well as artifacts from Egypt, Peru, the classical Mediterranean, Palestine, and Mesopotamia form part of a larger Ethnology collection that has been associated with the Redpath Museum since its founding in $1882 .{ }^{3}$ The Museum developed from the teaching collections of McGill University and was shaped by the research interests of natural history professor, John William Dawson. It was designed to exhibit a series of typical specimens and render these as accessible as possible to individual students and to professors for demonstrations to large classes. ${ }^{4}$

Archaeological and ethnological materials were intended to be part of the Museum from its inception, although subordinate in number and emphasis to other collections. This was made explicit in September 1880 , when Peter Redpath announced during the ceremonies attending the laying of the corner stone, that the new building was to serve as a "place of deposit and study of specimens in Geology, Mineralogy, Palaeontology, Zoology, Botany and Archaeology [italics added]. ${ }^{5}$

An early guide to the exhibits of the Museum notes a special area set aside for displays of cultural material adjacent to the Museum Hall on the main (second) floor. (Figure 1) Featured were objects from the Queen Charlotte Islands and British Columbia; antiquities from the site of "Hochelaga"; stone implements and other artifacts from prehistoric sites in Canada, Palestine, and Egypt; a series of skulls representing the "principal races of men"; objects from the New Hebrides; miscellaneous archaeological materials from England, the Canary Islands, and other locales; some casts of Greek and Assyrian "antiques"; a cast of the Rosetta Stone; and a large model illustrating the topography of Jerusalem. A goodly portion of the archaeological and "miscellaneous" collections exhibited in 1885, with the exception of Dawson's "Hochelaga" material, appears to have been lent or donated specifically for the meetings of the American Association for the Advancement of Science and the British Association for the Advancement of Science held in Montreal in 1882 and 1884. Much of this material is still part of the Redpath Museum. ${ }^{6}$

Doctors, missionaries, geologists, and travellers, many of whom had been enlisted to participate in various British imperial or commercial endeavours in different regions of the world, were among the Museum's early donors. These individuals were either affiliated with McGill University or associated in some way with John William Dawson. However, the Redpath's ethnological and archaeological collections, being neither systematic nor the work of professional anthropologists, were not acquired or displayed in a manner that accorded with the museological principles of the emergent discipline of anthropology, which was not represented at McGill until Frederick Voget was hired in $1948 . ?$

In 1925 McGill University became a depository for the collections of the disbanded Natural History Society of Montreal, which had been founded in 1827 . Specimens, artifacts, and books were allocated to the Redpath Museum, the McCord Museum, and the University Library. ${ }^{8}$ The addition of the Society's natural history collections made heavy demands on the 


\section{Excavating Collections}

Redpath Museum's limited space and precipitated the removal of etbnological and archaeological holdings to the ground floor of McGill's Strathcona Medical Building, where a separate Ethnological Museum was opened to the public in 1926. (Figure 2) The Palaeolithic holdings, including close to one thousand stone tools assembled by the geologist Henry Ami, remained in the Redpath Museum as part of the permanent palaeontological exhibit. ${ }^{9}$

The Ethnological Museum was the recipient of the Natural History Society of Montreal's collection of "miscellanies," including some 700 objects from Egypt, ancient Rome, the South Pacific, and Canada, which had been distributed around the University when the Society's holdings had been dispersed. Various other McGill collections contributed material to the Ethnological Museum, which also added more than 3,000 new donations over the years to its already substantial holdings. Exbibits were arranged geographically and included artifacts manufactured by Canada's indigenous peoples, weapons and implements gathered by the McGill-Congo Expedition of 1938-39, Garstang's Egyptian collection (see below), and miscellaneous Egyptian, Greek, and Carthaginian materials. ${ }^{10}$ The University's urgent need for space in support of the war effort closed the Ethnological Museum in 1941, but requests to study or borrow artifacts were still honoured. Although some of the ethnological collections remained in their cases, the Egyptian and Near Eastern materials were removed from the Strathcona Building and displayed in Divinity Hall, while other artifacts were used in temporary exhibits in the Redpath Library and Redpath Museum. Material not accommodated in any of the above locales joined that of the McCord in storage. ${ }^{11}$

The Ethnological Museum was reopened alongside the Arctic Institute for a brief period between 1947 and 1949. Still laid out by geographical plan with its focus upon "primitive man," the Museum included traditional and modern costumes, household goods, hunting and fishing gear, and modes of transport employed throughout the Canadian Arctic and Greenland; hunting equipment, ceremonial objects, and household goods of North American native peoples; textiles and pottery from Central and South America; Egyptian antiquities from the Garstang collection and three mummies illustrating burial customs; African weapons, household objects, "fetishes," and musical instruments from the Congo, Nigeria, Angola, and South Africa; and available for study, but not on public view, a "remarkable" group of objects from Polynesia and Melanesia, some assembled prior to $1850 .^{12}$

Following this two-year respite in the fortunes of the beleaguered Ethnological Museum, major portions of its collections were placed in storage, where they remained for over thirty years until their move to the Redpath in the early 1970s. ${ }^{13}$ Budgetary constraints closed the Redpath Museum to the public from 1971 to 1987 , during which time it resumed its original mandate of serving McGill's teaching and research needs. In recent years, efforts have once again been directed towards cultivating a public interest in the Museum's activities.

There are now some 17,000 artifacts in the Ethnology Collections of the Redpath Museum, the beginnings of which can be traced to Sir Williama Dawson's interest in human history and his belief in museums as teaching institutions. The history of the material comprising these collections has been a peripatetic one over the past hundred years, involving moves to various sites affiliated with McGill University, significant expansions and reductions in numbers of artifacts resulting from transfers from a variety of other McGill holdings, and alternating periods in storage and on public view. The most important rationalization in recent years has been the gradual relocation of all materials relating to Canada's indigenous peoples and domestic history in the McCord Museum and the consolidation of all other ethnological and archaeological collections, including Palaeolithic tools and classical coins, in the Redpath. Although the emphasis on various collections has shifted over the years, as have views regarding the delicate balance between public access on the one hand and teaching and research on the other, there has been a steady increase in scholarly interest towards the archaeological and ethnological holdings of the Redpath Museum, which is reflected in a growing number of recent publications. ${ }^{14}$

\section{THE MEROITIC CYLINDERS}

In the Redpath Museum's Egyptian and Sudanese collections, there are three large, hollow cylinders, each 


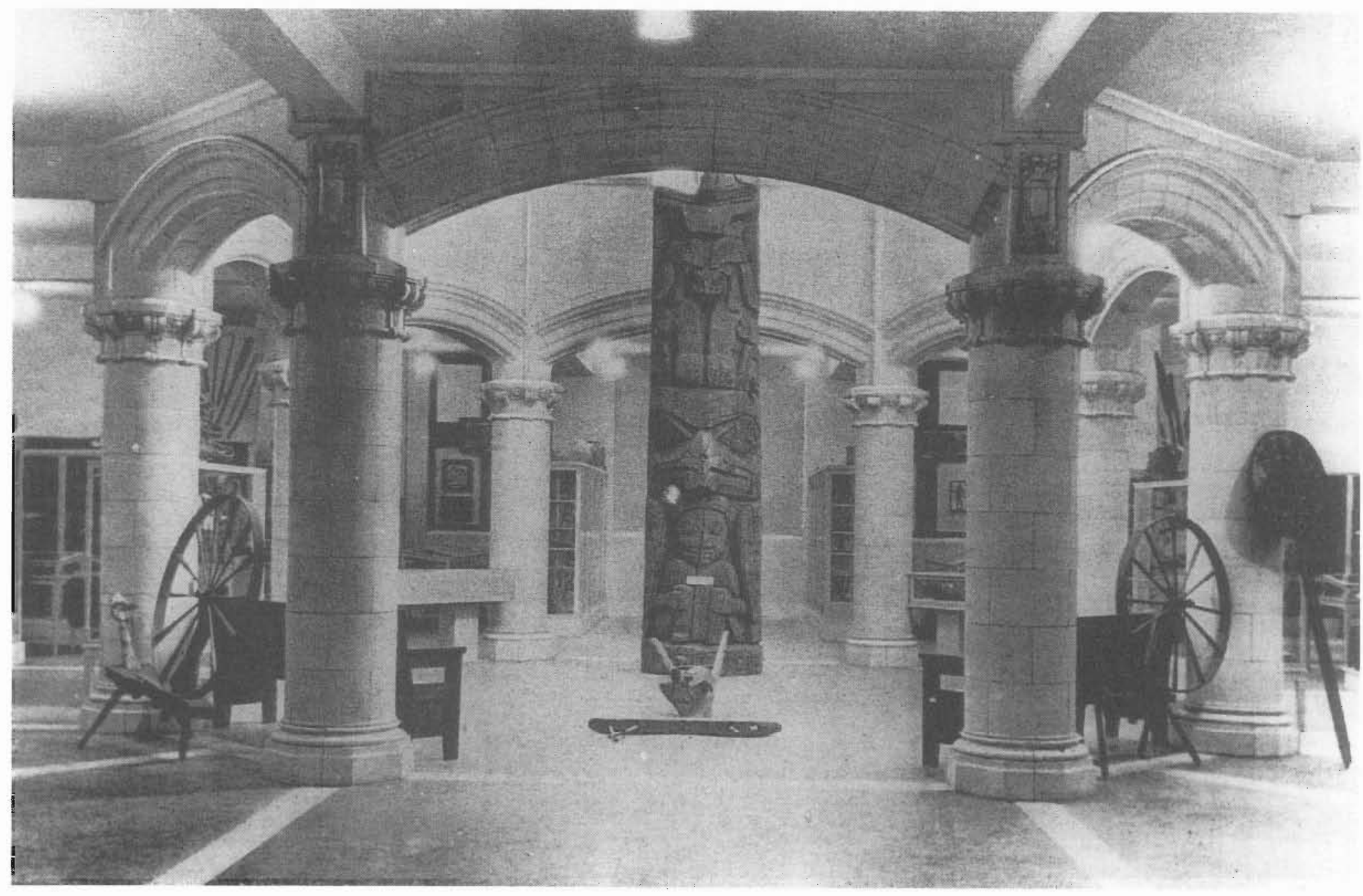

Figure 2. View of the Ethnological Museum showing the totem pole and other artifacts. (McCord Museum of Canadian History, Notman Photographic Archives) 
tapering slightly from bottom to top. Cylinders I and III are plaster casts, but Cylinder II, which is incomplete, is an original work of art consisting of a ceramic fabric covered with lustrous, blue-green, faience glaze; faience being a type of opaque glass that was popular in ancient Egypt. The cylinders average $34 \mathrm{~cm}$ in diameter and $40 \mathrm{~cm}$ high, and each of them is decorated with four horizontally-arranged panels containing images in low relief. The panels on Cylinder I portray rams and lions; while those on Cylinder II (Figure 3) probably originally showed four, winged, Egyptian goddesses; one of which has been completely lost. Cylinder III (Figure 4) is decorated with dancing scenes executed in a Hellenistic style.

Cylinder II and the originals from which the other two casts were made were excavated at the archaeological site of Meroe. This was the capital of the Kingdom of Kush, which flourished along the banks of the Nile in what is now the Republic of the Sudan from the eighth century B.C. until the fourth century A.D. Kush was the land that the ancient Greeks and Romans and the authors of the New Testament called Ethiopia. Although many aspects of the art and religion of this civilization were based on ancient Egyptian, and later on Hellenistic and Roman, prototypes, Kush had a distinctive culture. Between 730 and 667 B.C., its rulers conquered and held Egypt and for almost another thousand years they controlled the central part of the Nile Valley and adjacent steppes. ${ }^{15}$

The cylinders were reconstructed from fragments that John Garstang excavated at Meroe in 1914. Garstang lived from 1876 to 1956 and was Professor of Method and Practice of Archaeology at the University of Liverpool from 1907 to 1941. Despite his title, he was far from being one of the most advanced or methodical excavators of his day. Although, supported by various sponsors, he dug at Meroe for five winters from 1909 to 1914 , only the work of the first season was published in any detail in a book titled Meroe - The City of the Ethiopians, in 1911. ${ }^{16}$ Even this book resembles a modern preliminary account more than it does the definitive report of an excavation. For subsequent seasons, including the final one, when the remains of the cylinders were discovered, only the briefest "Interim Reports" are available. ${ }^{17}$

The fragments from which the cylinders were reconstructed were found in the course of a brief sondage, or trial excavation, carried out at a spot that Garstang labelled M 200. This was located a short distance east of the "Royal City" or "Royal Enclosure", a large, roughly rectangular area surrounded by a sandstone wall that appears to have contained the palaces of the royal family and the nobility and to have been the heart of the city. To the south of M 200 was the main temple of the god Amun, which abutted the east wall of the "Royal City". ${ }^{18}$ M 200 was variously described as a "stout building" or a "rectangular enclosure", which Phythian-Adams, one of Garstang's assistants, suggested might have been a garden attached either to the royal palace or to the Amun temple. ${ }^{19}$ Not enough work was done at the time or since to clarify the nature of this structure. We are informed only that the faience-covered fragments were found "on or about" the east wall of this structure.

The fragments that were recovered were pieced together to form substantial portions of three cylinders that were exhibited at the University of Liverpool in 1914, at which time they were also photographed. After the photographs were taken, still more pieces were added prior to the surviving casts being made. Following the Liverpool exhibition, Cylinder I went to the Toronto banker, Sir Edmund Walker, as his share of the year's finds. He in turn eventually donated this and other of Garstang's finds from Meroe to the Royal Ontario Museum, where they are now preserved as part of the extensive collections of the Egyptian Department. As far as the University of Liverpool was concerned, all traces of the other two cylinders and of the casts that had been made of them were lost.

As a result of this, when the Austrian Meroitic scholar Inge Hofmann published her study of these cylinders in 1989, she was able to work from excellent photographs of Cylinder I supplied by the Royal Ontario Museum, but for the other two had to rely on old photographs supplied by the archives of the School of Archaeology and Oriental Studies at the University of Liverpool. ${ }^{20}$ These photographs were not particularly satisfactory; the lighting often failed to reveal details of the decoration clearly and no view was available of one side of Cylinder III. On art historical grounds, Hofmann dated these cylinders to the late first century A.D., essentially the same date currently ssigned to them by the Hungarian Meroiticist László Török. Earlier, in a catalogue that he had prepared for an exhibition of the arts of ancient Nubia and the Sudan 

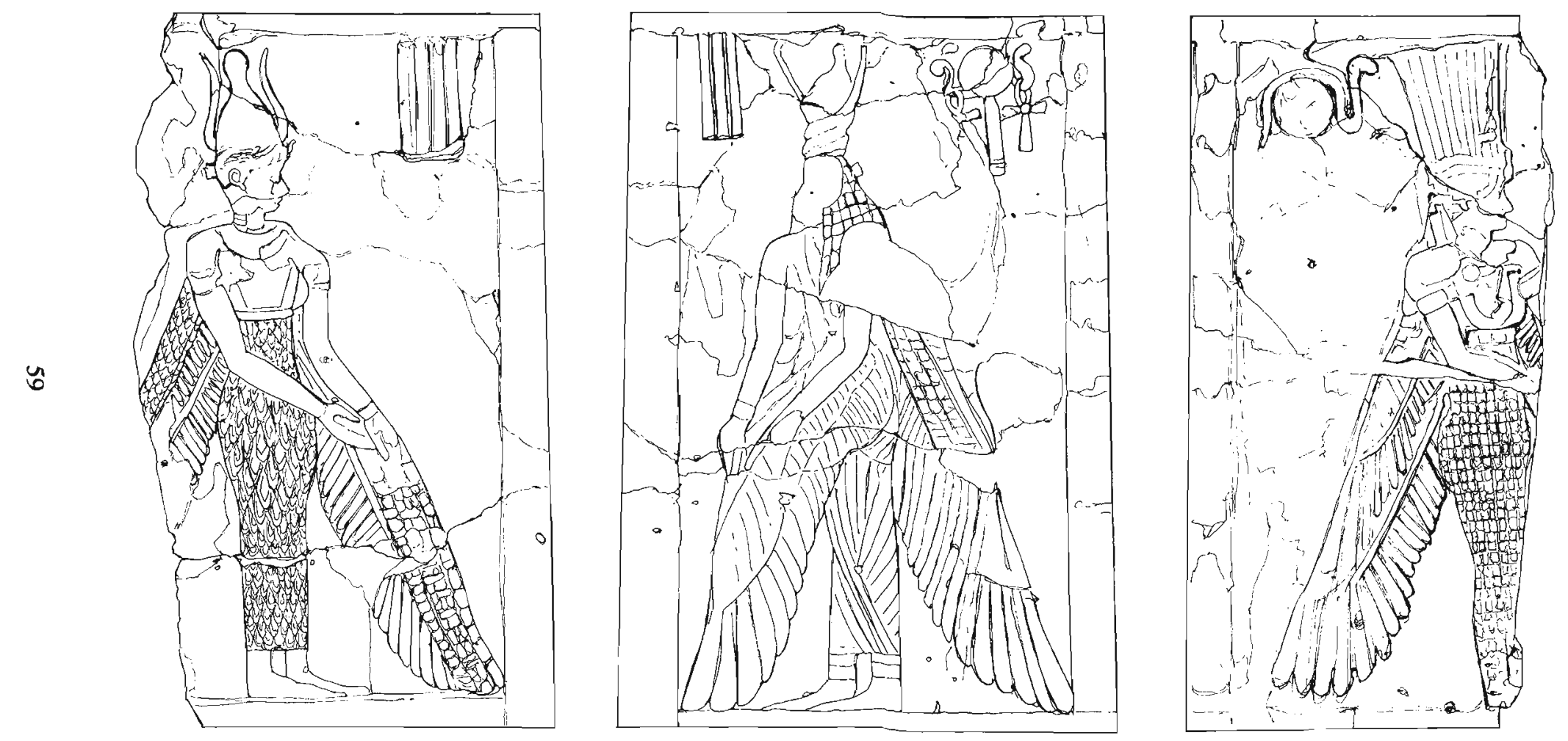

हू.

Figure 3. David Rose's drawing of Meriotic Cylinder II showing winged goddesses. They are from left to right: Satis, Mut (?), Anubis. 


\section{Excavating Collections}

mounted by the Brooklyn Museum in 1978, the East German Egyptologist Steffen Wenig dated them to the second or third centuries A.D., while Garstang had dated them to about 100 B.C. ${ }^{21}$ Wenig also described these cylinders as outstanding examples of the Meroitic "minor arts." 22

These scholars did not know that in 1923 Garstang had sold a "Collection of Egyptian and Meroitic Antiquities" to the Joint Board of the Theological Colleges associated with McGill University for the sum of $\$ 500 .^{23}$ The collection included approximately 20 objects from Meroe, mostly heavily restored ceramic vessels. The three faience cylinders were entered under a single number on the list that was sent with the collection to Montreal. There they are described as "Pillar in three sections." No other information accompanied these objects. There is some evidence that the cylinders may have been added to the collection in the course of negotiations in order to counter the Joint Board's objection to the price that Garstang was asking. There is no evidence that the purchasers were aware that two of the cylinders were casts.

Bruce Trigger's involvement with the cylinders began in 1990, when he was invited to contribute a paper to a festschrift honouring the 70th birthday of Jean Leclant, Professor of Egyptology at the Collège de France and Secrétaire Perpétuel of the Académie des Inscriptions et Belles-Lettres. Leclant not only is one of the world's most eminent Egyptologists but has made major contributions to understanding the history and archaeology of the Sudan and to Meroitic studies. Trigger therefore decided to publish the John Garstang material from Meroe that was held in the Redpath Museum as his contribution to the festschrift. Yet, when he examined the disparate objects that made up most of the collection, he concluded that these could provide the basis only for a very pedestrian study. Barbara Lawson then drew his attention to the three Meroitic cylinders. Trigger had glimpsed them many years before, covered with dust and piled in a remote and inaccessible corner of the basement of the Redpath Museum. Museum lore recounts that for many years the staff had regarded them as some kind of drain pipes. While Trigger had recognized their Meroitic character, he assumed erroneously that Garstang must have discovered a lot of glazed pottery and that these were only a few unimportant examples.
Although the cylinders had suffered some damage during the years of neglect that preceded the establishment of the Ethnology department within the Redpath Museum, under Lawson's care they had been cleaned and were now kept with the rest of the ethnology collections in a refurbished storage space. Seeing them clean and well lit for the first time, Trigger at once recognized their importance. $\mathrm{He}$ rushed to the McLennan Library and searched out volume 7 of the University of Liverpool's Annals of Archaeology and Anthropology, which he knew contained the fifth interim report on the excavations at Meroe. There were illustrations of the cylinders and a brief description of them. ${ }^{24}$ It was clear that Garstang and his assistants had been able to reconstruct only three cylinders, each of which was decorated in a different fashion. The Redpath Museum had all three. The initial excitement was dampened by the realization that two of the cylinders were only plaster casts; however, to have even one piece of Meroitic art that was as important as Cylinder II was a cause for celebration.

Careful examinations of photographs, followed by a visit to the Royal Ontario Museum, revealed that Cylinder I was a cast of the original now in Toronto. Break lines, pitting, and other incidental features excluded the possibility of dealing with multiple examples made in the same mould or copying the same design. A comparison of the Redpath Museum's Cylinder I with the original also demonstrated that the cast, while an old fashioned plaster one, was a reliable reproduction of the original. Comparisons of Cylinders II and III with the photographs from Liverpool published by Hofmann also showed that these were respectively the original and a cast of the other two cylinders that had been displayed in Liverpool in 1914. Inquiries revealed that no one knew what had happened to the original of Cylinder III; various possibilities were investigated without discovering where it had been sent. The Redpath Museum clearly possessed one of the missing cylinders and the only known cast of the second. It was also the only institution known to possess three-dimensional versions of all three cylinders. Recognizing that the details preserved on Cylinders II and III were so much clearer than they had been in the photographs available to Hofmann, Trigger concluded that he now had the basis for a paper that was worthy of Leclant. ${ }^{25}$ 


\section{Excavating Collections}
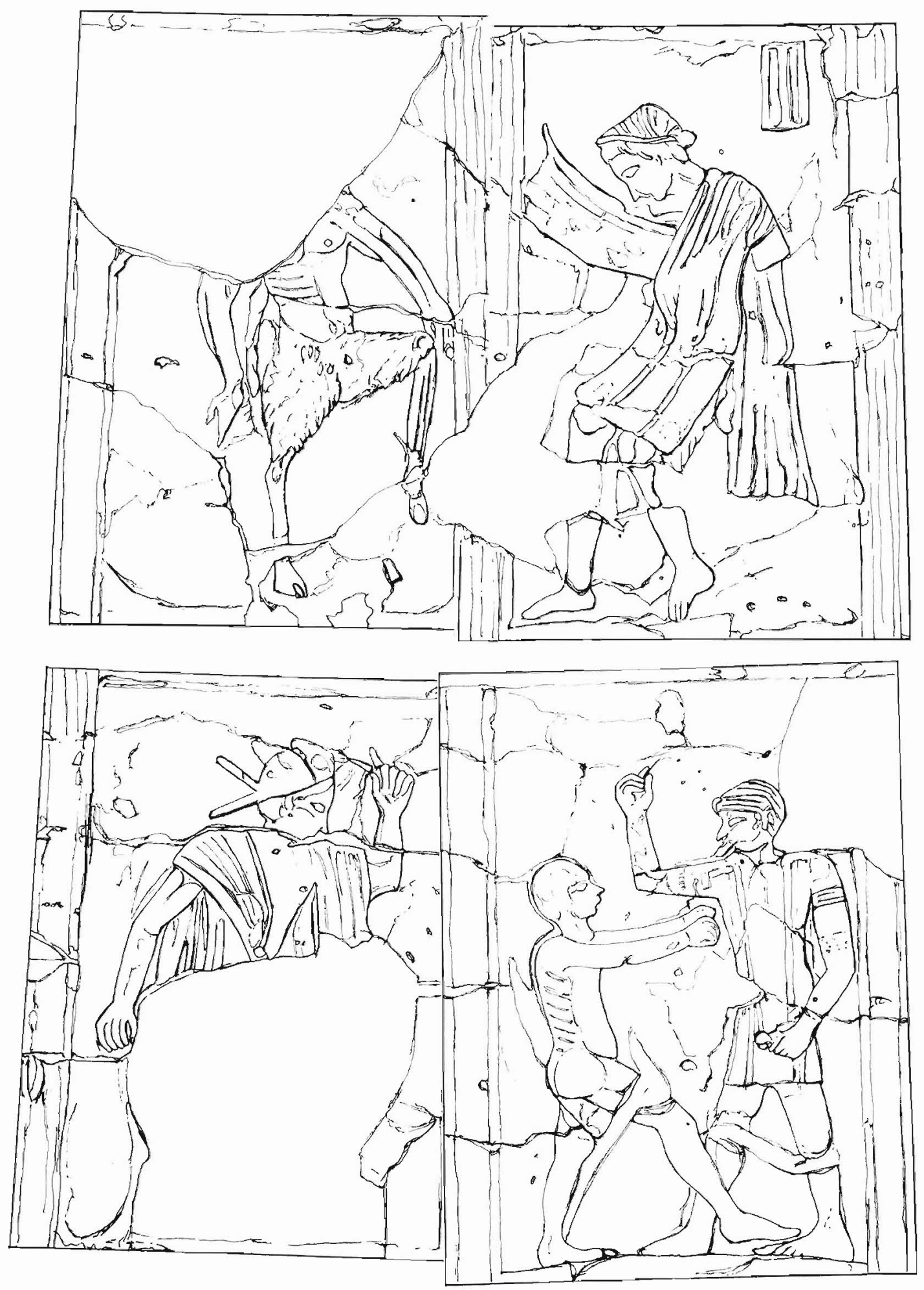

Figure 4. David Rose's drawing of Meroitic Cylinder III. The panels seem to represent the cult of the Greek God Bacchus. 


\section{Excavating Collections}

Because Cylinder I was already well known, the publication concentrated on Cylinder II and the cast of Cylinder III. To circumvent the limitations of even the best photographs, detailed drawings of the individual panels on these cylinders were prepared by artist David Rose with financial support from the Social Sciences Research Grants Subcommittee of McGill University. Rose made these drawings a collective effort, which combined his artistic skills and perceptiveness with Trigger's familiarity with Meroitic art and Lawson's keen eye for detail. Cylinder II was especially challenging, since even the preserved section is fragmentary and the surviving pieces are badly eroded in places. Much of the glaze was missing from the top of panel 2 and the left side of panel 3. In these areas it was possible to see how the relief was modelled in clay appliqué before a thin layer of blue faience glaze was added. Where the appliqué had fallen off, one could see scratched onto the original cylinder the designs that had guided further work.

Having three-dimensional versions of all three cylinders and the originals of two (one in Toronto and the other in Montreal), it was possible to compare the iconography and stylistic detail of these objects in greater detail than could have been done since at least the early 1920s. Cylinder I was decorated with two rams and two lions, one of the lions standing on a large cobra which rears up in front of him. These quadrupeds were in ancient times associated with the two most important gods of the Meroitic state; the ram with the Egyptian god Amun and the lion with the Meroitic deity Apedemak. The cobra appears to have been associated with Jebel Barkal, a site near the fourth cataract of the Nile which the Meroites identified as the spiritual centre of their kingdom. On the edge of the rocky hill at Jebel Barkal is a large natural formation that looks like a rearing cobra. ${ }^{26}$

On Cylinder II, Hofmann had been able to identify two of the three surviving winged goddesses as Satis and Anukis. These were minor Egyptian deities originally worshipped at Aswan in southern Egypt, but later they also featured prominently on the walls of Meroitic temples. Hofmann had been unable to determine the identity of the intervening goddess because of the poor quality of the photographs from which she had to work. A detailed study of the badly destroyed vulture headdress and double crown worn by this deity suggested that she was probably Mut, the wife of Amun, who also appears alongside Satis and Anukis on the walls of Meroitic temples. On the cylinder, Anukis is shown wearing around her neck a menyet collar, which the Egyptians associated with the goddess Hathor. This suggests that Hathor may have been the missing goddess whom Anukis was facing.

The cast of Cylinder III was far more complete and provided greater detail than the photographs that had been available to Hofmann and it was now possible to understand its symbolism for the first time. What appeared to be the main panel depicted a naked individual gyrating in front of a taller figure with a small beard and his right arm upraised. The other panels were decorated with a dancing satyr and two dancing men. These representations seem to portray the cult of the Greek god Bacchus, who was identified syncretistically with the Egyptian and Meroitic god Osiris. We have no way of knowing to what extent the Meroitic viewer would have read this cylinder as a depiction of Osiris worship, or simply of a Hellenistic cult.

The styles of the cylinders vary. The animals on Cylinder I are rendered in what is essentially a late Egyptian style, while the goddesses on Cylinder II display more of the Hellenistic influences that became common in Egyptian art during the period of Ptolemaic rule. Cylinder III is rendered in an almost completely Hellenistic fashion, with only the beard and hair (or wig) of the figure of Bacchus (or Osiris) displaying Egyptian elements. The simultaneous use of multiple styles was characteristic of late Meroitic art, but in few other instances are the three styles juxtaposed to the extent they are here.

Finally, what were these cylinders used for? Garstang believed that the cylinders, while unable to bear much weight on their own, would have been assembled on top of one another around a thick wooden post to form a faience pillar. A bit of mortar still adhering to the top of Cylinder II may have held such cylinders together. Cylinder I has the broadest diameter and a projection around the bottom; hence it is likely to have been a basal element. Yet careful measurements of Cylinders II and III indicate that, while either could have been set above Cylinder I, they could not have been positioned above one another. This supports Hofmann's contention that Garstang found the remains of more than one pillar. ${ }^{27}$ Another 


\section{Excavating Collections}

large, faience-glazed piece of pottery from Meroe now at the Royal Ontario Museum may have been part of the lotus-shaped capital of such a column. Hofmann suggests that a number of faience-clad columns, each about $2 \mathrm{~m}$ high, may have supported a "baldachin" or some other small ceremonial structure at M $200 .^{28}$

\section{PALAEOLITHIC SCULPTURES}

More recently, the collections of the Redpath Museum have played a major role in both authenticating and elucidating the archaeological context of a spectacular set of European Upper Palaeolithic sculptures that were purchased by the artist Pierre Bolduc in a Rue Notre Dame antique shop in Montreal in 1990. While the research is not yet complete, the work that has been done so far has established the source and approximate age of these specimens and unravelled the fascinating history of how they came to be in Montreal. These objects, six human figurines and a stylized animal face, were originally part of the private collection of Louis Jullien, a chemist and antiquities dealer from Marseille who obtained them from the Grimaldi caves in Liguria, Italy, one of the most important centres of Palaeolithic archaeological finds in Europe. These seven caves, located on a prominent cliff projecting into the Mediterranean Sea immediately adjacent to the border with France, contained extensive Middle and Upper Palaeolithic deposits and were exploited by amateur and professional archaeologists, as well as site looters, throughout the last half of the nineteenth century. In November 1883, Jullien rented space in the Barma Grande cave at Grimaldi from a local landowner (a businessman named François Abbo) and began four months of excavations during which he removed over eight metres of archaeological deposits from two trenches along the cave walls and found over 40,000 artifacts ${ }^{29}$ (Figure 5). The renting of land for archaeological excavation was a not uncommon practice at that period. On February 5,1884 Jullien discovered a human burial, but a dispute with Abbo enupted over ownership of the bones and Jullien's work terminated shortly thereafter. ${ }^{30}$ Jullien later requested permission to excavate a nearby cave named the Grotte du Prince, but was refused by the railway authorities who owned the land. ${ }^{31}$ In a letter written many years later, he admitted that he carried out clandestine excavations in the upper levels of the Grotte du Prince at some time after 1884. In the course of both these excavations, Jullien discovered a total of fifteen sculptures, but for reasons that are as yet unclear he kept their existence secret until $1896 .{ }^{32}$

Because of the mysterious circumstances surrounding their discovery, and because their subject matter (stylized nude women with exaggerated sexual characteristics) was previously unknown in Upper Palaeolithic art, the Grimaldi figurines became embroiled in a bitter academic debate. In 1896, Jullien sold one specimen, claimed to be the second that he had discovered in the Barma Grande, to the Musée des Antiquités Nationales near Paris. This specimen was published by Salomon Reinach in 1898, and was immediately denounced as a fraud by Gabriel de Mortillet, then the most influential archaeologist in France, and Emile Rivière, who had previously excavated many of the Grimaldi sites. ${ }^{33}$ The vituperative nature of the debate was extreme even by nineteenth century archaeological standards. Mortillet, for example, accused Reinach of being interested in obscene statues of obese nude women because of his own sexual "predilections", and insinuated that scholars who accepted the authenticity of these "fakes" were "amateurs. ${ }^{34}$

Probably as a result of this debate, Jullien became very cautious in discussing the figurines with professional archaeologists. He sold six other specimens to a friend and fellow collector, Edouard Piette, and emigrated to Montreal around 1900 with the rest of his collection. Prior to this time Jullien frequently had visited Montreal on business and had married Quebec-born Augustine Lebel in 1868. When Piette died in 1906, his collection was bequeathed to the Musée des Antiquités Nationales. The seven Grimaldi figurines were eventually accepted as genuine since they had been found prior to unquestionably authentic female figurines executed in the same style. ${ }^{35}$ The Musée des Antiquités Nationales also acquired the correspondence between Piette and Jullien, from which Henri Breuil, the celebrated French authority on Palaeolithic cave art, learned of the existence of the eight missing specimens. Breuil was able to obtain information about these pieces in 1913-14 through an intermediary, the Abbé Dupaigne, who taught history at the Grand Séminaire de Montréal. However, Dupaigne was shown only the three least elaborate sculptures that Jullien possessed. ${ }^{36}$ When Jullien moved to Arthabaska in 1914, Breuil lost contact and the specimens effectively disappeared. 


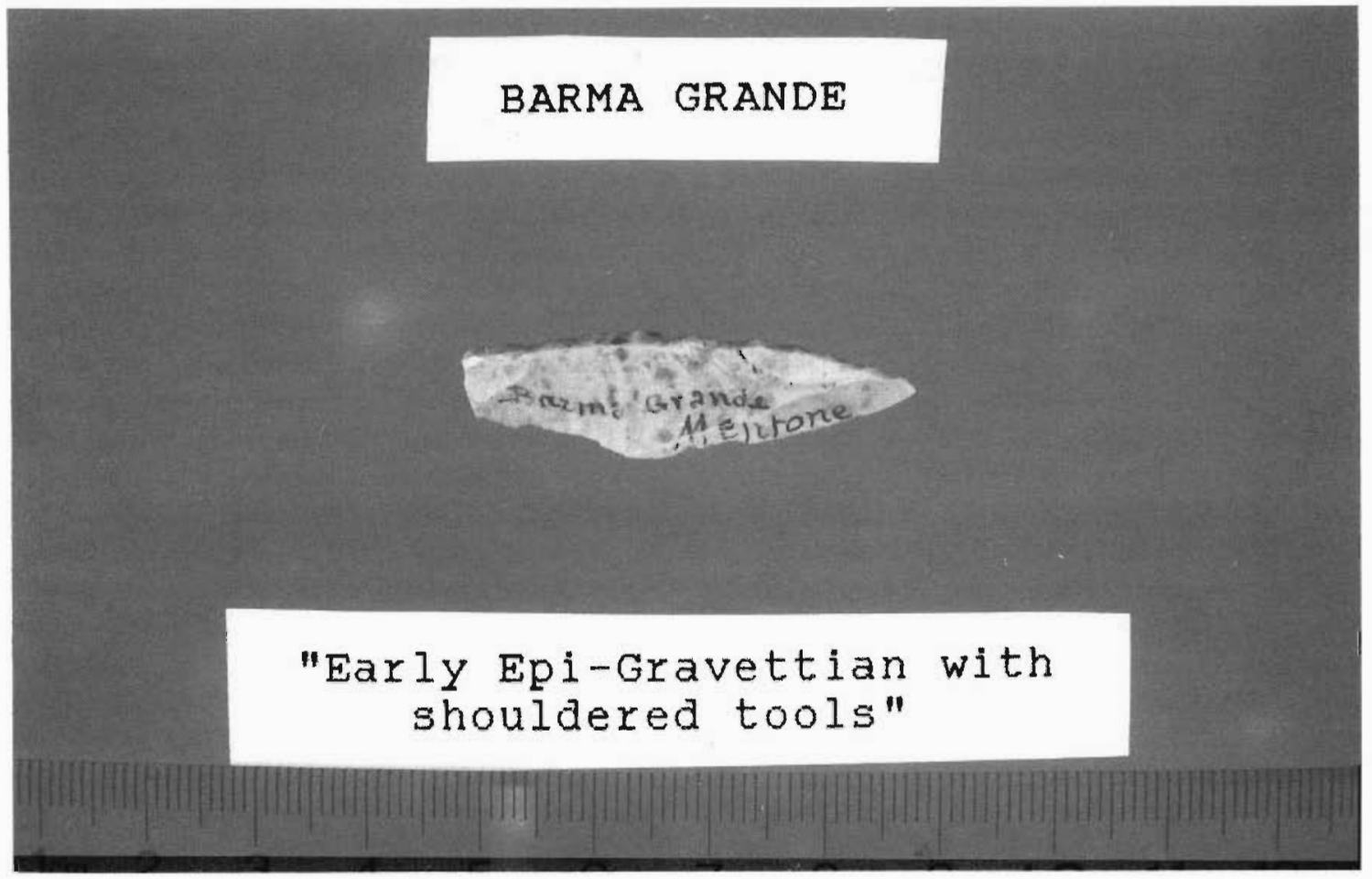

Figure 5. Microgravette from Barma Grande. This variety of small pointed backed blade is a common element in both the Gravettion and Epi-gravettion industries of Italy. The writing on these tools by Jullien was a crucial source of information in reconstructing the Barma Grande archaeological sequence.

Jullien died in 1928. A daughter sold one figurine to the Harvard Peabody Museum in $1944,{ }^{37}$ but seven remained in obscurity in Montreal until 1990, when Pierre Bolduc purchased five of them. These specimens, along with about 130 stone tools that were part of the same lot, were brought to McGill for identification in October 1993. They were examined by Michael Bisson, a professor of archaeology in the Anthropology Department of the Faculty of Arts who has long been associated with the Redpath Museum. Immediately recognizing the importance of these objects, Bisson secured Bolduc's permission to coordinate their scientific study. Subsequent investigation by Bolduc located the remaining two figurines and permission was obtained to include them in the study that was already underway. The fact that Jullien was known to have made two donations of archaeological specimens to the Redpath Museum in March and September 1895 was the critical factor in attracting Bolduc to McGill and securing the complete cooperation of the owners of these important pieces for their study.
The seven Grimaldi figurines of the lost Jullien collection are among the best preserved and most elaborate Early Upper Palaeolithic art works known from Western Europe. Before archaeologists could hope to interpret the meaning of these complex symbols, a number of technical issues needed to be resolved. These included establishing the authenticity of the figurines, their date, and the archaeological site and context from which they came. The archaeological collection from Grimaldi that has long been in the Redpath Museum has proved essential in all three of these endeavours.

Bisson recognized that two separate questions had to be answered in order to authenticate the figurines. First, their connection to the original Jullien collection had to be verified and, second, the possibility that they might be nineteenth-century fakes had to be ruled uut. The specimens found by Bolduc in the antique store were associated with stone tools mounted for display on red velvet cards, with labels noting the "Mentone" caves as the provenance. The artifacts Jullien donated 


\section{Excavating Collections}

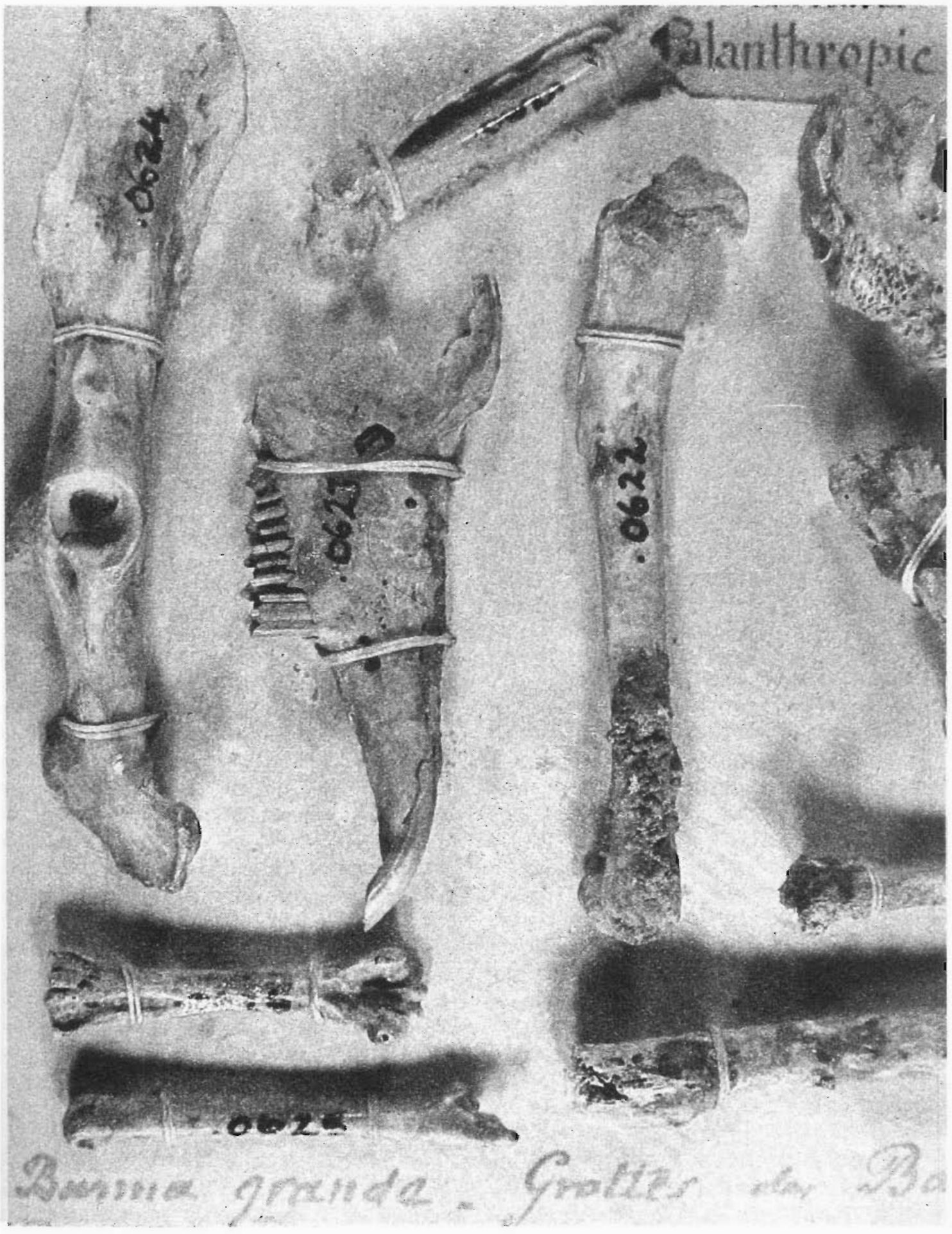

Figure 6. Rodent and bird bones mounted for display by Jullien. Notes on the reverse of the card indicate that they were found in "hearths" at six metres depth. These are some of the specimens presently being subjected to accelerator radiocarbon dating. 


\section{Excavating Collections}

to McGill in 1895 were mounted on identical cards marked with the same handwriting (Figure 6). Bolduc contacted the previous owners of the figurines, who are descendants of Jullien and provided additional evidence that the specimens were in the possession of their family at the time Jullien moved to Montreal. Two of the specimens match descriptions made by Dupaigne. There is no doubt that these were the pieces missing since the time of Breuil's enquiries in 1913-1914.

Techniques of forensic detection were applied to resolve the suggestion of possible fraud by Jullien. Randall White, a specialist in the study of European Palaeolithic art and professor at New York University, has conducted a comprehensive microscopic examination of the figurines in order to identify tool marks and other evidence of manufacturing techniques. He found no evidence that metal tools or modern abrasives were used in their manufacture. Bisson's microscopic examination of sediment adhering to the figurines identified close matches to the sediment found on Jullien's stone tools in the Redpath Museum (see below). The degree of patination on all the specimens, the intrusion of cave sediment deep into shrinkage cracks on the two ivory figurines, and the presence on some of the specimens of tiny growths of cave breccia, invisible to the naked eye are additional features that could not have been produced by a nineteenth-century artifact faker. Bisson and White therefore concluded that all seven sculptures are ancient and came from the Grimaldi caves.

The precise dates of the sculptures remain uncertain. On stylistic grounds they fall clearly within the range of variation of Gravettian "Venus" figurines, having featureless faces and prominent breasts, abdomens, and buttocks. The consensus today, based on style and a recent analysis of the Barma Grande burial data, is that they are Gravettian or Early Epi-Gravettian in date (c. 20,000-27,000 B.C.). ${ }^{38}$ Unfortunately, the degree of chronological control is insufficient to allow more precise interpretations to be made. The figurines are bighly diverse in form; no two are alike, although they share enough design elements to be clearly part of a single iconographic tradition. Their variation might be the result of change over time; or they might be contemporary and differ for symbolic or technical reasons, such as being made from different materials which had to be worked differently; or they even might reflect the different personal styles of individual sculptors.

Fortunately, the Redpath Museum collection from Grimaldi offers a unique opportunity to refine the chronology of these objects. The archaeological specimens Jullien donated to McGill include about 800 stone tools and animal bones (Figure 7). Although no notes from Jullien concerning the provenance of these objects have been found in the McGill Archives, an index card catalogue indicates that someone at the Redpath Museum was told at which site each piece had been found. This catalogue probably was prepared by the geologist Henry Ami, who coordinated the display of Palaeolithic materials at the Museum in the early 1930s. The bulk of the collection is from Barma Grande, but a number of animal bones and a few lithic artifacts are attributed to the Grotte du Prince. That information is further corroborated by notations on many tools indicating the site where they were found, and in some cases even the depth below the surface or the month of discovery. It is likely that most of the formal tools in the McGill Grimaldi collection were originally mounted on numbered cards similar to those found in the antique shop. It also seems that like the recently recovered, card-mounted specimens, the McGill ones had been at least partly organized according to the depth at which the specimens had been found. Because the Redpath specimens were not catalogued randomly, the catalogue numbers assigned to individual artifacts may hold clues as to which specimens were found near to one another in the site. This hypothesis is being tested through the analysis of sediment described below.

Fortunately, because Jullien did not clean either his stone or his bone specimens thoroughly, bits of sediment can be found adhering to many of them. Variations in these sediments can provide useful clues concerning the site and levels within sites from which these specimens came. In order to reconstruct and try to date the stratigraphic sequence of these materials, Bisson is presently inspecting each artifact and bone fragment under a binocular dissecting microscope at $50 \mathrm{X}$ in order to record the colour, texture, and mineral composition of any adhering sediments. Because a few of the animal bones have labels listing the depth below the surface of the site at which they were found, there are a few fixed reference points showing the sediment 


\section{Excavating Collections}

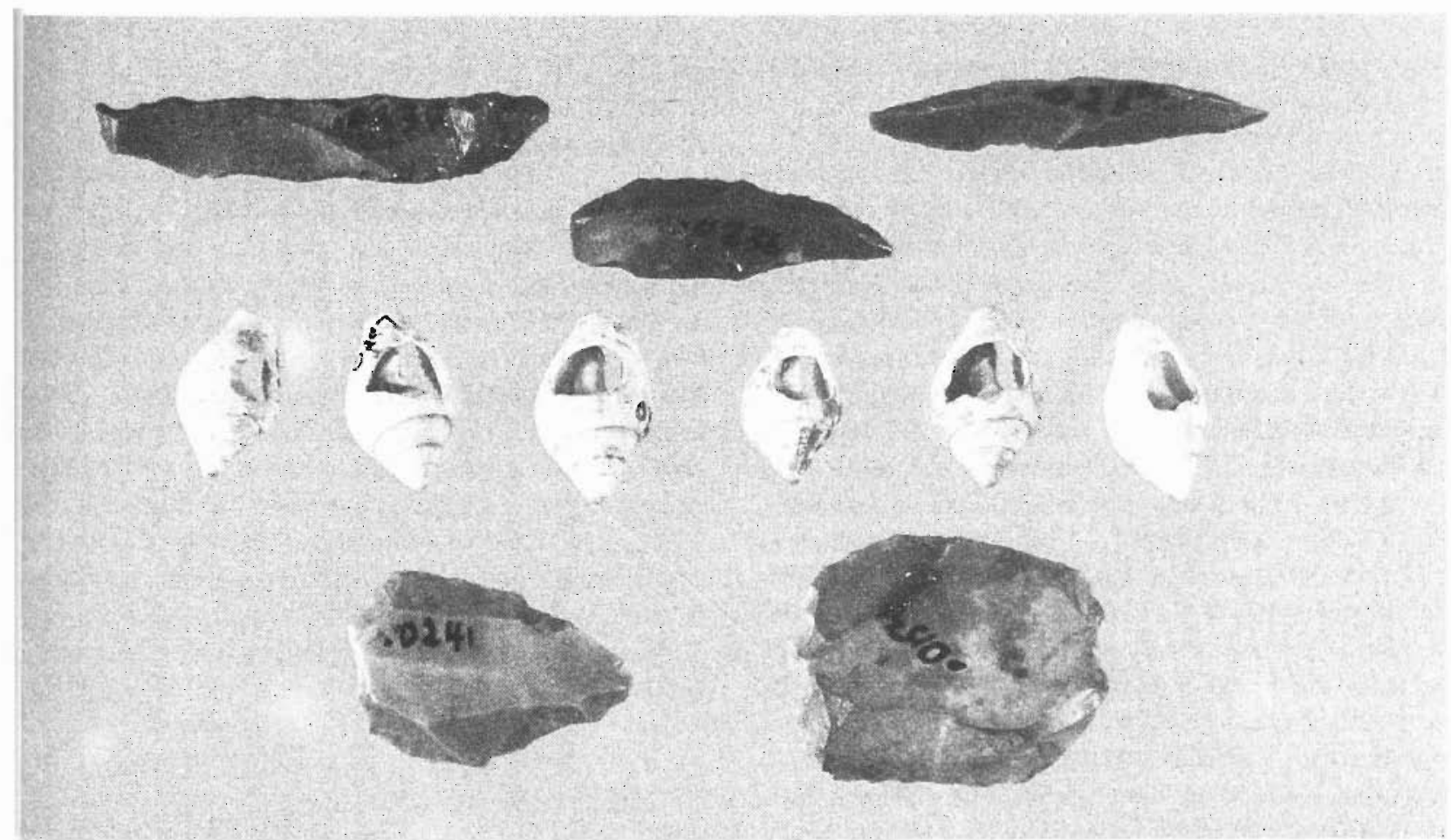

Figure 7. Backed blades, microgravettes, scrapers, and Columbella rustica shell beads found by Jullien at between three and five metres depth in the Barma Grande. These are probably later Epi-gravettion in date. At least some of the figurines are certainly associated with these specimens.

characteristics at $3.5 \mathrm{~m}, 6 \mathrm{~m}$, and $8 \mathrm{~m}$. This encompasses most of the total depth excavated by Jullien, and includes all of the layers in which he claimed to have found statuettes. If a detailed sedimentary sequence can be reconstructed, the sediment on the statuettes can be used to link them to specific levels. Bones from the Barma Grande and the Grotte du Prince, including all those bearing depth labels will be subjected to accelerator radiocarbon dating, which gives highly precise readings and requires only tiny amounts of each specimen to assign calendrical dates to the sequence. Preliminary results of the sediment comparisons indicate that the two figurines made of ivory are from the Grotte du Prince and somewhat older than the five specimens fashioned from chlorite and serpentine, which are all from the Barma Grande. With the addition of absolute dates, these figurines will be better documented than almost any other Gravettian female figurines from Western Europe. $^{39}$

Placing the figurines within the chronological sequence at the Grimaldi caves will only be the first step in reconstructing their archaeological and cultural context. With the exception of the Grotte des Enfants, none of the early excavations in Upper Palaeolithic deposits at Grimaldi was adequately published. ${ }^{\$ 0}$ This is especially true of the Barma Grande, where even the so-called professional excavations of Riviére failed to produce a stratigraphic cross-section or numerical summary of artifacts. ${ }^{41}$ Although the collection in the Redpath Museum was certainly subject to excavator bias, in that Jullien discarded pieces that he did not find interesting, and critical spatial relationships will never be known, important information still can be gained from the typological and technological analysis of the material that is available. For example, interesting techniques appear to have been employed to economize on the amount of stone being used to make implements during the Gravettian and Epi-Gravettian periods. Worn out microblade cores were sometimes reused as burins (gravers), scrapers, and wedges. In addition, many of the tools appear to have organic residues adhering to their cutting edges, which, when identified, may provide important clues concerning the specific activities that were taking place at the site. Through 
these detailed studies of the stone tools and animal bones in the Redpath collection, the cultural context of the figurines will become better known.

\section{CONCLUSION}

These case studies illustrate two generally unappreciated aspects of the research potential of the Redpath Museum's long inaccessible and little known archaeological collections. While the teaching value of these collections has been recognized and exploited since the early 1970s, the historical, scientific, and cultural importance of most individual artifacts remains to be determined. Because this must be done one artifact or set of artifacts at a time, it is a slow task that draws upon the knowledge and skills of many different people. The identification of long lost Meroitic art treasures (both an original and casts) has permitted a more detailed study of these pieces and contributed significantly to a better understanding of Meroitic elite culture. Continuing research on the archaeological material in the Redpath Museum by McGill staff and students and by visiting scholars will enhance in many unanticipated and important ways our understanding of these collections and our knowledge of the past. We can expect to learn even more from the larger and richer collections of ethnographic material in the Redpath Museum.

The second project we described illustrates how even apparently mundane objects, such as stone tools and bones, can provide important information relating to major discoveries made outside the Redpath Museum. By helping to date and pinpoint the origin of Jullien's Upper Palaeolithic figurines, artifacts from the Redpath Museum have played a crucial role in interpreting the most important discovery relating to Palaeolithic art made in the last twenty-five years.

In 1970 it was proposed to close the Redpath Museum and dispose of its collections. Had that happened, McGill University would have lost valuable teaching material. In addition, it would have abandoned artifacts before it had any clear sense of their research potential. Such action would have been inimical to research on an international level. Had the Jullien collection still not been in the Redpath Museum in 1993, it might have taken much longer, or even been impossible, to establish the connection between this material and the figurines. That in turn would have greatly diminished the possibility of interpreting a find that is of world-wide interest.

In the future museums are going to become increasingly important for archaeological research. Archaeologists will devote more of their time to developing the kind of skills required to make effective use of these collections. Small as the Redpath Museum's archaeological collections may be compared to those found in major public museums, their value as sources of information about the past will grow as archaeological sites that can still be excavated become ever rarer. All of this confirms the wisdom and farsightedness of Stanley Frost, when, as Vice-Principal of McGill University, he decided, in a time of great economic stringency, to preserve the Redpath Museum and restore it, according to Dawson's original plan, as a centre for university teaching and research. 


\section{Notes}

1. For examples, see Bruce G. Trigger, A History of Archaeological Thought (Cambridge, Cambridge University Press, 1989), passim; James R. Sackett, "From de Mortillet to Bordes: A Century of French Palaeolithic Research," in Towards a History of Archaeology, ed. by Glyn Daniel (London, Thames and Hudson, 1981), 85-99.

2. Leslie E. Wildesen, "The Study of Impacts on Archaeological Sites," in Advances in Archaeological Method and Theory, ed. by Michael B. Schiffer (New York, Academic Press, 1982), v. 5, 51-96; for an early discussion of site conservation, see Lili Kaelas, "Cultural Heritage, Archaeological Museums, and Public Opinion, "in To Illustrate the Monuments, ed. by J.V.S. Megaw (London, Thames and Hudson, 1976), 13-22.

3. For details regarding the bistory of the Redpath Museum's Ethnology collections, see Barbara Lawson, Collected Curios: Missionary Tales from the South Seas (Fontanus Monograph Series, Montreal, McGill University Libraries, 1994).

4. John William Dawson, In Memoriam of Peter Redpath (Montreal, Witness Printing House, 1894), 17. The early development of the Redpath Museum and its istural history collections under Dawson is discussed by Susan Sheets-Pyenson, Cathedrals of Science (Montreal, MoGill-Queen's University Press, 1988).

5. As reported in the Montreal Gazette and cited in Dawson, In Memoriam of Peter Redpath, 21. The ame statement appears in the official deed of Peter Redpatb's donation of the Redpath Museum to McGill, dated 24th August 1882.

6. Redpath Museum, Guide to Visitors to the Peter Redpath Museum of McGill University (Montreal, MeGill University, 1885), 3-4; Redpath Museum, Report on the Peter Redpath Museum of McGill University, nos. 1, 2, 3 (Montreal: McGill University, 1882, 1883, 1884). The archaeological site that Dawson identified as that of "Hochelaga" is now called the Dawson site: see James F. Pendergast and Bruce G. Trigger, Cartier's Hochelaga and the Dawson Site (Montreal, McGill-Queen's University Press, 1972).
The New Hebrides material is discussed in Lawson, Collected Curios.

7. To evaluate the Redpath Museum in terms of contemporary anthropological practice relating to material culture collections in North America see Franz Boas, "Museums of Ethnology and their Classification," Science, v. 9 (1887), 137-141, 485-486, 587-589; Douglas Cole, "The Origins of Canadian Anthropology, 1850-1910, "Journal of Canadian Studies, v. 8 (1973), 33-45; Curtis Hinsley, Savages and Scientists: The Smithsonian Institution and the Development of American Anthropology, 1846-1910 (Washington, D.C., Smithsonian Institution, 1981); Hinsley, "From ShellHeaps to Stelae: Early Anthropology at the Peabody Museum," in Objects and Others: Essays on Museums and Material Culture (History of Anthropology, v. 3), ed. by G.W. Stocking, Jr. (Madison, University of Wisconsin Press, 1985), 49-74; I. Jacknis, "Franz Boas and Exhibits: On the Limits of the Museum Method of Anthropology," in Objects and Others, 75-111; B.G. Trigger, "Giants and Pygmies: The Professionalization of Canadian Archaeology," in Towards a History of Archaeology, ed. by Glyn Daniel (London, Thames and Hudson, 1981), 76-79; Trigger, Natives and Newcomers: Canada's "Heroic Age" Reconsidered (Montreal: McGill-Queen's University Press, 1985), 39-43.

8. Stanley Frost, "Science Education in the Nineteenth Century: The Natural History Society of Montreal, 1827-1925, "McGill Journal of Education, v. 17, n. 1 (1982), 40-41; N.H.S.M. "Natural History Society Inventory." Manuscript dated March 7, 1906, unpaginated [1906-1925]. Addendum titled "Distribution of Material from the Natural History Society of Montreal," entries are dated from March 1925 to October [1925], unpaginated. Blacker-Wood Library, McGill University, Montreal.

9. Cyril Fox, A Survey of McGill University Museums (Montreal, McGill University, 1932), 10, 13.

10. Fox, A Survey of McGill University Museums, 14$15,22$.

11. The McCord Museum was closed to the public in 1936 because of inadequate funding and recommendations made by an external examiner (Fox, 


\section{Excavating Collections}

A Survey of McGill University Museums). Although the closure was intended as a temporary measure, the McCord's status remained the same for more than thirty years.

12. Ethnological Museum. Typescript Guide to Displays of McGill University's Ethnological Museum. Single page, folded in booklet form (1947). On file, Ethnology Collections, Redpath Museum.

13. See T. Clark and A. Turnham [Johannsen], "McGill University Museums: A Report of Progress 1855-1950." Typescript, 18 pp. McGill University Archives, RG 41, C.3 (1950). Although the suggestion in Fox's 1932 survey to amalgamate the prehistoric and historical holdings of McGill into a single museum building was never carried out, several of the collections have since been regrouped.

14. There have been approximately fifty publications citing artifacts or dealing exclusively with ethnological or archaeological material in the Redpath collections since the last century. For examples of recent archaeological studies, see M. Attas, "The Fineness of Tarentine Didrachmas, "in Papers in Greek Archaeology and History in Memory of Colin D. Gordon, ed. by J.M. Fossey (Amsterdam, J.C. Gieben, 1987), 99-115; M. Attas, J.M. Fossey, and L. Yaffe, "Variations of Ceramic Composition with Time: A Test Case Using Lakonian Pottery," Archaeometry, v. 24, n. 2 (1982), 181-191; David Berg, "A Fragmentary Book of the Dead Papyrus Belonging to McGill University, "Journal of the Society for the Study of Egyptian Antiquities, v. 13, n. 2 (1983), 107-119, pl. i-iv; Berg, "The Archaeological Context of the Egyptian and Nubian Antiquities in the Redpath Museum," Fontanus, v. 3 (1990), 117-130; Berg, "Some Ramesside Fragments," in Studien zur Altägyptischen Kultur, ed. by Hartwig Altenmüller and Dietrich Wildung (Hamburg, Helmut Buske Verlag, 1990), 75-106, Tafeln 1-4; C. El Mahdy, Mummies, Myth and Magic in Ancient Egypt (London, Thames and Hudson, 1989); G. Frame, "A Babylonian Omen Text in the Redpath Museum," Annual Review of the Royal Inscriptions of Mesopotamia Project, v. 5 (1987), 7-10; G. Frame, D. Frayne, and G. McEwan, "Cuneiform Texts in the Collections of McGill University, Montreal, "Annual Review of the Royal Inscriptions of Mesopotamia Project, v. 7 (1989); F.T. Hedgcock, A. Moreau, H.
Marshall, and G. Kennedy, "Nondestructive Physical Examination of Corroded Lead," in Proceedings of the 24th International Archaeometry Symposium, Smithsonian Institution, 14-18 May 1984, ed. by J.S. Olin and M.J. Blackman (Washington, D.C.: Smithsonian Institution Press, 1986), 243-248; P. Horne and R. Ireland, "Moss and a Guanche Mummy: An Unusual Utilization," The Bryologist, v.94, n. 4 (1991), 407-408; P. Horne and D. Jarzen, "Dragon's Blood and Mummies: Modern Science Unravels Ancient Mysteries/Sang de dragon et momies: d'anciens mystères sous 1'éclairage de la science moderne," Biome, v. 12, n. 2 (1992), 2; P. Horne, B. Lawson, and A. Aufderheide, "Examination of the Guanche Mummy RED-1, " Proceedings of the First International Conference on Mummy Studies, Tenerife (1994, in press); G.J.P. McEwan, "A Seleucid Tablet in the Redpath Museum," Annual Review of the Royal Inscriptions of Mesopotamia, v. 4 (1986), 35-36; R. Virr, B. Lawson, G.M. Woloch, and F. Shlosser, "The McGill University Collection of Greek and Roman Coins: New Evidence for its History, "Fontanus, v. 4 (1991), 109-124; G.M. Woloch (ed.), The McGill University Collection of Greek and Roman Coins, v. 1-3 (Amsterdam, B.R. Grüner Publishing Company, 1987); T. Yetrman, "The Redpath Museum Tablet Collection," Recueil de travaux et communications de l'association des études du Proche-Orient Ancien, v. 1 (1983), pp. 511; K. Zahn, "The McGill University Egyptian Mummy Collection," Recueil de travaux et communications de l'association des études du ProcheOrient Ancien, v. 2 (1984), 25-27; E. Zoïtopoúlou and J.M. Fossey, La Collection des antiquités grécoromaines de l'Université McGill. Fascicule I -Les Lampes gréco-romaines (Amsterdam: J.C. Gieben, 1992).

15. Peter L. Shinnie, Meroe: A Civilization of the Sudan (London, Thames and Hudson, 1967).

16. John Garstang, A.H. Sayce, and F.Ll. Griffith, Meroe: The City of the Ethiopians: Being an Account of a First Season's Excavations on the Site, 1909-1910 (Oxford, Oxford University Press, 1911).

17. These reports appeared in the Annals of Archaeology and Anthropology (University of Liverpool), vols. 3 (1910) to 7 (1914-16). 
18. John H. Robertson, "History and Archaeology at Meroe," in An African Commitment: Papers in Honour of Peter Lewis Shinnie, ed. by Judy Sterner and Nicholas David (Calgary: University of Calgary Press, 1992), 35-50.

19. John Garstang, "Fifth Interim Report on the Excavations at Meroë in Ethiopia: Part I. - General Results," Annals of Archaeology and Anthropology, v. 7 (1914-16), 6; W.J. Phythian-Adams, "Fifth Interim Report on the Excavations at Meroë in Ethiopia: Part II. - Detailed Examination, "Annals of Archaeology and Anthropology, v. 7 (1914-16), 13-14.

20. Inge Hofmann, "Die Glasierten Säulenfragmente von M 200 (Meroe-Stadt)," Beiträge zur Sudanforschung, v. 4 (1989), 107-129.

21. For dates, see ibid., 128-129; László Török, "Kush and the External World, "Meroitica, v. 10 (1989), 133; Steffen Wenig, Africa in Antiquity: The Arts of Ancient Nubia and the Sudan, Vol. 2, The Catalogue (Brooklyn: The Brooklyn Museum, 1978), 94; Garstang, "Fifth Interim Report," 6.

22. Wenig, Africa in Antiquity, 91.

23. David Berg, "The Archaeological Context of the Egyptian and Nubian Antiquities in the Redpath Museum," Fontanus, v. 3 (1990), 116130.

24. Phythian-Adams "Interim Report," 13-14.

25. Bruce G. Trigger, "The John Garstang Cylinders from Meroe in the Redpath Museum at McGill University," Hommages à Jean Leclant, ed. by C. Berger, G. Clerc, and N. Grimal (Cairo: Institut Français d'Archéologie Orientale, 1994, in press).

26. Timothy Kendall, "Discoveries at Sudan's Sacred Mountain of Jebel Barkal Reveal Secrets of the Kingdom of Kush," National Geographic Magazine, v. 178, n. 5 (1990), 111-123.

27. Hofmann, "Die Glasierten Säulenfragmente," 128.

28. Ibid., 127-128.

29. Léon Pales, "Les ci-devant vénus stéatopyges aurignaciennes," in Santander Symposium: Actas del
Symposium de Arte Prehistorico, Santander-Asturias, ed. by Martín Almagro y Basch and M.A. Garcia Guinea (Santander, 1972), 217-260.

30. Marcellin Boule, Fossil Men: Elements of Human Palaeontology (Edinburgh, Oliver and Boyd, 1923).

31. Margherite Mussi, "L'Utilisation de la stéatite dans les grottes des Balzi Rossi (ou Grottes de Grimaldi)," GalliaPréhistoire, v. 33 (1991), 1-16.

32. Pales, "Les ci-devant vénus."

33. Salomon Reinach, "Statuette de femme nue découverte dans une des grottes de Menton," L'Anthropologie, v. 9 (1898), 26-31; Gabriel de Mortillet, "Statuette fausse des Baoussé-Roussé," Bulletin de la Société d'Anthropologie de Paris série VI, v. 9 (1898), 146-152; Emile Rivière, "Discussion," Bulletin de la Société d'Anthropologie de Paris série VI, v. 9 (1898), 152-153.

34. Mortillet, "Statuette fausse."

35. Henri Breuil, "Renseignements inédits sur les circonstances des trouvailles des statuettes aurignaciennes des Baoussé-Roussé," Archivio per l'Antropologia e la Etnologia, v. 58 (1918), 281-286.

36. Pales, "Les ci-devant vénus."

37. Alexander Marshack, "Une figurine de Grimaldi "redécouverte: analyse et discussion," L'Anthropologie, v. 90 (1986), 807-814.

38. Margherite Mussi, "On the Chronology of the Burials Found in the Grimaldi Caves," Anthropologia Contemporanea, v. 9, n. 2 (1986), 95-104.

39. Henri Delporte, L'Image de la femme dans l'art préhistorique (Paris, Picard, 1933).

40. L. de Villeneuve, Marcellin Boule, R. Verneau and Emile Cartailhac, Les Grottes de Grimaldi (BaousséRoussé). 2 vols. (Monaco: Imprimerie de Monaco, 1906-1912).

41. Emile Riviére, L'Antiquité de l'homme dans les Alpes-Maritimes (Paris, Baillére, 1887). 